\title{
CONTROL OF HISTONE AND DNA SYNTHESIS WITH CANAVANINE, PUROMYCIN, AND POLIOVIRUS ${ }^{1}$ \\ W. Wilbur Ackermann, D. C. Cox and S. Dinka \\ Department of Epidemiology and Virus Laboratory, School of Public Health, University of Michigan, Ann Arbor, Michigan
}

Received May 6, 1965

In cell free systems, histones were reported to block the function of DNA, in its own replication (Gurley, 1964) and in RNA synthesis (Huang and Bonner, 1962; Barr and Butler, 1963). Further, consequent to infection with poliovirus (Sokol, et al., 1965; Cox, et al. , 1965) or ME virus (Holoubek and Rueckert, 1964) a progressive inhibition of cellular DNA synthesis occurs. This is preceded by a stimulated rate of histone synthesis, which is subsequently depressed below normal. The action of canavanine as a specific antagonist of arginine and that of puromycin as a broad general inhibitor of protein synthesis (Darken, 1964) are accepted as a basis for interpretation of the experimental findings in this paper which relate to the effects of these inhibitors on synthesis of histone and DNA in cells under conditions of viral infection and various culture media. Canavanine was found to inhibit histone synthesis and to stimulate DNA synthesis in normal and infected cells.

1 This investigation was supported by Public Health Service Grant No. AI 05876-01 from the National Institutes of Allergy and Infectious Diseases, National Institutes of Health. 
Materials. A continuous line of cells, HeLa, was grown as monolayers in Roux bottles with Eagle's basal medium (1955). Periodically cells and fluid were inoculated into special media (Chanock, et al. , 1962) to ensure that they were free of mycoplasma and bacteria. The Mahoney strain of type I poliovirus used was grown in HeLa cells, sedimented by centrifugation and resuspended in phosphate buffered saline when used as inoculum.

C14-1-arginine, uniformly labeled, and $\mathrm{H}^{3}$-thymidylate, randomly labeled, were obtained from Schwartz Bioresearch, Inc. while $\mathrm{H}^{3}-$ thymidine, randomly labeled, was purchased from Volk Radiochemical Company.

Methods. DNA was determined by the method of Burton (1956); protein by the Low ry method (1951); radioactivity by use of an Automatic Liquid Scintillation Spectrometer (Kinard, 1957).

In some experiments DNA was extracted with phenol (Colter, et al. , 1962) and further separated from RNA and polysaccharides (Martinez Segovia, 1965) while in others it was extracted with hot trichloroacetic acid from preisolated DNP (deoxyribonucleoprotein). DNP was prepared (Mirsky and Pollister, 1946) from isolated nuclei (Hogeboom, et al. , 1952). Histone fractions from DNP were obtained by three succcsive extractions with 20 percent $\mathrm{HCl}$ (1.25 N) in ethanol and with $0.2 \mathrm{~N} \mathrm{HCl}$ (Johns and Butler, 1962; Johns, et al. , 1961)

Experimental. To cultures of HeLa cells in Roux bottles, with $60 \mathrm{ml}$ of Eagle's basal medium containing no arginine, various supplements were added alone or in combinations as indicated in Table 1: thymidine, thymidylate ( $4 \mu \mathrm{gm} / \mathrm{ml}$ ), a combination of all deoxyribonucleotides of 
DNA $(4 \mu \mathrm{gm}$ each $/ \mathrm{ml})$, arginine $(50 \mu \mathrm{gm} / \mathrm{ml}$ or $1 \mu \mathrm{gm} / \mathrm{ml})$, puromycin (0. $4 \mu \mathrm{gm} / \mathrm{ml})$, poliovirus $\left(1 \times 10^{9} \mathrm{PFU}\right)$. After 3 hours incubation (Exp. 1, 2, 3,5), one of the following isotopic labeled compounds was added: $\mathrm{H}^{3}$-thymidine $(1 \mu \mathrm{c} / \mathrm{culture}), \mathrm{H}^{3}$-thymidylate $(1 \mu \mathrm{c} / \mathrm{culture})$ or $\mathrm{C}^{14}$-arginine (2 uc/culture). The experiment was terminated after one additional hour at $37^{\circ} \mathrm{C}$. In experiments 1,4 , and 5, the histones and DNA were isolated from preisolated DNP. Phenol extraction was used to isolate DNA from whole cells in experiments 2 and 3. In experiment 4 the isotope and supplements were added simultaneously and the experiment terminated after one hour. In each case the incorporation of isotope into DNA or histone was determined and recorded in the table. Results and Discussion. $\mathrm{H}^{3}$ label of thymidylate was incorporated into DNA of HeLa cells. The incorporation was enhanced 12 percent by addition of the four unlabeled deoxyribonucleotides of DNA (Table, Exp. 1). Under the latter condition, inhibition of protein synthesis (by action of Puromycin) for 4 hours resulted in a reduced rate ( 40 percent) of DNA synthesis (Table, Exp. 3) presumably as a result of the decay of essential enzymes, kinases or polymerase, which are not replenished. Although this broad inhibitor of protein synthesis may inhibit histone synthesis - which would make more DNA primer available - the net result was an inhibition of DNA synthesis because the limiting factor was enzyme.

In contrast inhibition of DNA synthesis consequent to poliovirus infection ( 64 percent; Table, Exp. 1,2,3) was nullified by inhibition of histone synthesis (by the action of canavanine; Table, Exp. 2) and the presumed increase in available DNA primer. This suggests that under 
the influence of poliovirus, DNA primer is limiting in the synthesis of

\begin{tabular}{|c|c|c|c|}
\hline Exp. No. & $\begin{array}{l}\text { Isotopic } \\
\text { Label }\end{array}$ & Supplements* & $\begin{array}{c}\text { DNA } \\
\text { Counts } / \mathrm{min} / \mu \mathrm{gm}\end{array}$ \\
\hline \multirow[t]{4}{*}{$1^{+}$} & $\mathrm{H}^{3}-\mathrm{TMP}$ & TMP & 1.76 \\
\hline & " & $d N$ & 2.13 \\
\hline & $"$ & $\mathrm{dN}+$ Virus & 0.775 \\
\hline & $"$ & $\mathrm{TMP}+\mathrm{Can}$ & 2.07 \\
\hline \multirow[t]{4}{*}{$2^{+}$} & $\mathrm{H}^{3}-\mathrm{TMP}$ & $\mathrm{dN}$ & 3.34 \\
\hline & $"$ & $\mathrm{dN}+\mathrm{Can}$ & 5.11 \\
\hline & $"$ & $d N+$ Virus & 1.80 \\
\hline & $"$ & $\mathrm{dN}+$ Virus + Can & 3.30 \\
\hline \multirow[t]{4}{*}{$3^{+}$} & $\mathrm{H}^{3}-\mathrm{TMP}$ & $\mathrm{dN}$ & 5.24 \\
\hline & 11 & $d N+P u r$ & 3.13 \\
\hline & $"$ & $\mathrm{dN}+$ Virus & 1.89 \\
\hline & 11 & $\mathrm{dN}+$ Virus + Pur & 1.70 \\
\hline \multirow[t]{5}{*}{4} & $\mathrm{H}^{3}-\mathrm{T}$ & $\operatorname{Arg}(50)$ & 37.3 \\
\hline & 11 & No Arg & 41.3 \\
\hline & 11 & No Arg + Can & 103.8 \\
\hline & & & $\begin{array}{c}\text { Histone } \\
\text { Counts } / \mathrm{min} / \mu \mathrm{gm}\end{array}$ \\
\hline & & & $b^{-}$ \\
\hline \multirow[t]{2}{*}{5} & $\mathrm{C}^{14}-\mathrm{Arg}$ & $\operatorname{Arg}(1)$ & 12.5 \\
\hline & 11 & $"+$ Can & 7.7 \\
\hline
\end{tabular}

TABLE. Effect of poliovirus, puromycin, canavanine, and arginine on the incorporation of isotopic label of $\mathrm{H}^{3}$-thymidylate, $\mathrm{H}^{3}$-thymidine and C 14 -arginine into DNA or histone. $* \mathrm{TMP}=$ thymidylate $(4 \mathrm{\mu gm} / \mathrm{ml})$; $\mathrm{dN}=$ all deoxyribonucleotides of $\mathrm{DNA}(4 \mu \mathrm{gm}$ each $/ \mathrm{ml}) ; \mathrm{Can}=$ canava nine $(32 \mu \mathrm{gm} / \mathrm{ml})$; Arg (50) $=\operatorname{arginine}(50 \mu \mathrm{gm} / \mathrm{ml}) ; \operatorname{Arg}(1)=\operatorname{arginine}$ ( $1 \mathrm{\mu gm} / \mathrm{ml}) ; \mathrm{T}=$ thymidine; Pur $=\operatorname{puromycin}(0.4 \mu \mathrm{gm} / \mathrm{ml}) .+$ All cultures, of Exp. 1 and 3 contained arginine $(50 \mu \mathrm{gm} / \mathrm{ml})$; tho se of Exp. 2 contained $1 \mu \mathrm{gm} / \mathrm{ml}$ arginine. $a$ and $b$ refer respectively to ethanol$\mathrm{HCl}$ and $\mathrm{HCl}$ soluble histones.

DNA. This may result from the stimulated synthesis of histone (Cox, et al. , 1965; Holoubek and Rueckert, 1964) which occurs early, one to two hours after infection.

Puromycin does not reverse the effect of poliovirus on DNA as does canavanine (Table, Exp. 3) because its action is bruader and in its own right causes in time the essential enzymes to become limiting and DNA synthesis to be inhibited. If these agents acted independently, 
then some reversal of the viral effect at least to the level of the puromycin effect should be attained - synthesis of DNA would increase from 1.89 to 3.13 (Table, Exp. 3) which is not the case.

Canavanine $(32 \mu \mathrm{gm} / \mathrm{ml})$ also increases the rate of DNA synthesis of uninfected HeLa cells under a variety of conditions: pretreatment with canavanine for three hours in the presence of arginine $(50 \mu \mathrm{gm} /$ ml) and thymidylate $(4 \mu \mathrm{gm} / \mathrm{ml})$ increased the rate of DNA synthesis 18 percent; pretreatment for three hours with a low concentration of arginine ( $1 \mu \mathrm{gm} / \mathrm{ml}$ ) and the four deoxyribonucleotides of DNA ( $4 \mu \mathrm{gm}$ each $/ \mathrm{ml}$ ) present increased the rate 53 percent; within one hour after the simultaneous addition of $\mathrm{H}^{3}$-thymidine and canavanine without arginine the rate was increased 150 percent (Tablc, Exp. 1, 2, 4).

In contrast to the effect on DNA synthesis, canavanine blocks the incorporation of $\mathrm{C}^{14}$ from arginine into histone (Table, Exp. 5) of HeLa cells. It seems unlikely that the effect on DNA synthesis results from a conservation of arginine and a redirection of it into pyrimidine synthesis via orotic acid since: deletion of arginine from the medium does not reduce the rate of DNA synthesis indicating that usually it is not limiting (Table, Exp. 4), and the stimulatory effect of canavanine occurs in the presence of high levels of the four deoxyribonucleotides, proximal precursors of DNA, which should bypass the requirement for arginine. If the stimulatory effect of canavanine is mediated through the inhibition of histone synthesis, the mechanism would seem to be a more direct one involving the interaction of histone and DNA primer as suggested by cell free experiments.

$\underline{\text { References. }}$

Barr, G.C., and Butler, J.A.V., Nature, 199, 1170 (1963). 
Burton, K. , Biochem. J., 62, 315 (1956).

Chanock, R. M. , Hayflick, L., and Barile, M. F., Proc. Natl. Acad. Sci. U.S. , 48, 41 (1962).

Colter, J.S., Bran, R.A., and Ellen, K. A.O., Biochem. Biophys. Acta, 55, 31 (1962).

Cox, D. C., Sokol, F., Dinka, S., and Ackermann, W.W., Bact. Proceedings, 106 (1965).

Darken, M. A. , Pharm. Rev. , 16, 223 (1964).

Eagle, H. , J. Exptl. Med., 102, 37 (1955).

Gurley, L. R., Irwin, J. L., and Holbrook, D. J., Biochem. Biophys. Res. Comm., 14, 527 (1964).

Hogeboom, G. H. , Schneider, W. C. , and Striebick, M. J., J. Biol. Chem. , 196, 111 (1952).

Holoubek, V., and Rueckert, R. R., Biochem. Biophys, Res. Comm. 15,166 (1964).

Huang, $\bar{R}$. C., and Bonner, J., Proc. Natl. Acad. Sci. U. S., 48, 1216 (1962).

Johns, E.W., and Butler, J.A.V., Biochem. J., 82, 15 (1962).

Johns, E. W., Phillips, D. M.P., Simson, P., and Butler, J. A. V., Biochem. J., 80, 189 (1961)

Kinard, F. E. , Scientific Instruments, 28, 293 (1957).

Lowry, O. H., Rosebrough, N.J., Fan, A. L., and Randall, R.J., J. Biol. Chem., 193, 265 (1951).

Martinez Segovia, Z.M., Sokol, F., Graves, I. L., and Ackermann, W. W. , Biochem. Biophys. Acta, 95, 329 (1965).

Mirsky, A. E., and Pollister, A.W., J. Gen. Physiol., 30, 117 (1946).

Sokol, F., Cox, D. C., Dinka, S., and Ackermann, W. W., Proc. Soc. Exptl. Biol. Med., (submitted for publication). 